\title{
Efect of vitamin A suplementation: a systematic review
}

\author{
Efeito da suplementação de vitamina A: uma revisão sistemática
}

\author{
Marcela Martins Soares ${ }^{1}$ \\ Mariane Alves Silva ${ }^{1}$ \\ Pauliana Pimentel Coelho Garcia ${ }^{2}$ \\ Luciana Saraiva da Silva ${ }^{3}$ \\ Glauce Dias da Costa ${ }^{1}$ \\ Raquel Maria Amaral Araújo ${ }^{1}$ \\ Rosângela Minardi Mitre Cotta ${ }^{1}$
}

\footnotetext{
${ }^{1}$ Ciência da Nutrição, Departamento de Nutrição e Saúde, Universidade Federal de Viçosa. Ed. Centro de Ciências Biológicas II Centro Universitário. 36570000 Viçosa MG Brasil. marcela.m.soares@ufv.br ${ }^{2}$ Estratégia Saúde da Família Santa Clara Coelhas/Sol Nascente. Viçosa MG Brasil. ${ }^{3}$ Curso de Nutrição, Faculdade de Medicina, Universidade Federal de Uberlândia. Uberlândia MG Brasil.
}

\begin{abstract}
To evaluate the effect of vitamin A supplementation in postpartum infants and women on serum retinol levels and breast milk. The databases Medline, PubMed, Lilacs and SciELO were consulted. The descriptors used were vitamin A, dietary supplement, child, postpartum period, infant and nutrition programs policies. Search found 7432 articles. After elimination of duplicity and application of eligibility criteria, 8 studies remained. All evaluated the effect of vitamin $A$ supplementation on immediate postpartum, five studies used retinyl palmitate supplementation, one with retinyl palmitate and two did not specify the form of supplementation. Six studies evaluated colostrum and two included supplementation of children. It was found that supplementation in the puerperium increases the concentrations of serum retinol and breast milk, however, this result was in the short term and was relevant when the previous concentrations of the mother were low. When maternal serum concentrations are adequate, the retinol content in milk does not change, with little relevance for children. Further studies should be performed to evaluate the effect of megadoses supplementation on serum concentrations of children.
\end{abstract}

Key words Vitamin A, Nutritional supplements, Postpartum period, Infant
Resumo Avaliar o efeito da suplementação de vitamina $A$, em lactentes e mulheres no pós-parto, nos niveis de retinol sérico e no leite materno. Foram consultadas as bases de dados Medline, PubMed, Lilacs e SciELO. Os descritores utilizados foram: vitamin A, dietary supplement, child, postpartum period, infant e nutrition programs policies. A busca identificou 7432 artigos. Após eliminação da duplicidade e aplicação dos critérios de elegibilidade permaneceram 8 estudos. Todos avaliaram o efeito da suplementação de vitamina A no pós parto imediato, cinco estudos utilizaram a suplementação com retinil palmitato, um com palmitato de retinila e dois não especificaram a forma de suplementação. Seis estudos avaliaram o colostro e dois incluíram a suplementação de crianças. Encontrou-se que a suplementação no puerpério aumenta as concentrações de retinol sérico e do leite materno, no entanto, este resultado foi a curto prazo e foi relevante quando as concentrações prévias da mãe eram baixas. Quando as concentrações séricas maternas encontram-se adequadas, pouco se altera o teor de retinol no leite, tendo pouco relevância para as crianças. Mais estudos devem ser realizados para avaliar o efeito da suplementação com megadoses nas concentrações séricas de crianças.

Palavras-chave Vitamina A, Suplementos nutricionais, Período pós-parto, Lactente, Programas e nutrição e alimentação 


\section{Introduction}

Vitamin A is an essential micronutrient for the body and is associated with the proper functioning of the visual system, maintenance of epithelial integrity, red cell production, growth and development, immune and reproductive function, among others. Since the human body does not produce this vitamin is necessary adequate daily intake in order to prevent this micronutrient deficiency and harm the proper functioning of the body ${ }^{1-8}$.

According to data from the World Health Organization (WHO) vitamin A deficiency affects about 190 million pre-school children in the world and is considered one of the major nutritional deficiencies in children ${ }^{4}$. In Brazil, this deficiency is considered a public health issue in view of the data from the latest Demographic and Health Survey National (PNDS, 2006) that identified the deficiency in $17.4 \%$ of children under five years and $12.3 \%$ of women ${ }^{4,9}$.

With the aim to prevent and/or control Vitamin A Deficiency (VAD) in Brazil, the National Supplementation of Vitamin A Program (NSVAP) was set by the Ministry of Health, through Ordinance No. 729 on May 13, 2005. This program aims to supplement children from 6 to 59 months and women in the immediate postpartum period with megadoses of vitamin A, targeting to reduce mortality from infections. It was initially deployed in endemic areas, but later expanded to all municipalities with official cases of vitamin A deficiency in children and/or nursing mothers or those in the "bolsa família" pro$\operatorname{gram}^{7,10-12}$.

A review conducted by Mason et al..$^{13}$ question the effectiveness of reducing infant mortality and subclinical deficiency of vitamin A, by supplementation program with high doses of this vitamin A. According to the author, studies on the effectiveness of supplementation with megadoses, since 1994, did not confirmed impact on mortality. The supplementation has effect on mortality from infections, especially diarrhea and measles, which has shown reduction in their occurrence due to improved immunization coverage and practices of oral rehydration. Thus, the actual impact may be small or non-existent ${ }^{13}$.

Therefore, it is of great importance to identify the results of supplementation in nursing mothers and infants in order to know the impact of these strategies, the dosages used and whether supplementation is characterized as a short or long-term benefit. Mason et al. ${ }^{13}$ found that the use of megadoses is not enough to maintain regular serum retinol concentrations until the next dosage and do not reduce mortality, highlighting the importance and need for new policies to be rethought. Thus, the present review aims to evaluate the effect of vitamin A supplementation among risk groups (infants and women postpartum), with regard to retinol levels in the serum and in the breast milk, in perspective to provide subsidies to Nutrition and Feeding Programs and Policy.

\section{Methods}

\section{Protocol and registration}

This is a systematic review of the literature based on the PRISMA (Preferred Reporting Items for Systematic Reviews and Meta-Analyses) method $^{14}$.

\section{Eligibility criteria}

The eligibility criteria used were: articles that presented original data on serum concentration of retinol in infants or concentration of retinol in maternal breast milk of both mothers, both after supplementation. The study was restricted to these groups, since they are more vulnerable to vitamin A deficiency and because they are attended by the supplementation program of this micronutrient. We do not limit ourselves to the study type, and it was only necessary to evaluate and / or compare the supplementation impact on breast milk and blood from supplemented individuals. We did not delimit the year of publication and the selected languages were English, Portuguese and Spanish, such strategies aimed at broadening the search. Were excluded studies that used secondary data, dissertations, theses, articles assessing unhealthy populations or that do not match risk groups for this deficiency and that assessed multiple supplemental nutrients.

\section{Information sources}

Information about the studies were obtained from the databases Medline (National Library of Medicine, USA), PubMed, Lilacs (Latin American and Caribbean Health Sciences) and SciELO (Scientific Electronic Library Online) in the period between 04 April to 23 June 2016.

The descriptors used in the search were chosen after consultation with the Health Sciences 
Descriptors (DeCS) and Medical Subject Headings (MeSH), which are: vitamin A, dietary supplement, child, postpartum period, infant and nutrition programs policies and their counterparts in Spanish and Portuguese. The following combinations were used: vitamin A AND dietary supplements AND child; vitamin A AND dietary supplements AND postpartum period; vitamin A AND dietary supplements AND infant; vitamin A AND dietary supplements AND nutrition programs and policies.

\section{Search strategy}

The identification and selection of the papers in all the researched databases were made independently by three researchers, respecting the eligibility criteria and without the use of filters. Initially the duplications between the bases were eliminated. Next, was performed a refinement to select studies regarding the theme addressed, by reading the titles and abstracts. In the event of disagreement between the investigators, the study was re-evaluated and the doubts obtained in the process of applying the eligibility criteria were discussed until a consensus was reached among the members.

\section{Study selection}

The selection of papers are represented in the flow chart below (Figure 1).

\section{Extraction of data}

To evaluate the effect of vitamin A supplementation was elaborated a table with the main studies findings, which were extracted in duplicate by the authors, allowing them to discuss the doubts and disagreements found.

The variables of this instrument were: author/year, local/design, group sample, purpose and used dosage (Table 1).

\section{Evaluation of study quality}

The GRADE method was used to evaluate the studies quality included in the review. This instrument assesses factors that may diminish (risk of bias, inconsistency of results, inaccura$c y$, indirect evidence and publication bias) or increase (magnitude of effect, dose-response gradient, and decrease of confounders) the quality of evidence only applies to observational studies. The experimental studies begin the evaluation with high quality score (4 points), while the observational ones start with low quality (2 points). Then, for each present factor that can decrease the quality of the evidence, it is deducted from 1 to 2 points, according to the magnitude of the factor. The presence of factors that increase the quality of evidence adds the initial score to 1 to 2 points. After the final sum, the studies were classified as low ( $<2$ points), average ( 3 points) and good quality ( $>2$ points) (Table 2 ). We did not identify publication bias and selective reporting of studies.

\section{Results}

The search in the data bases with the selected descriptors resulted in the initial identification of 7432 papers/articles. Later, 5058 duplicate articles were eliminated, resulting in a total of 2374 articles. Of these, 2331 were excluded because they did not behold the theme, after reviewing the titles and abstracts. At this stage of the study, remained 43 eligible papers. Of these, 35 were excluded because they did not include the established eligibility criteria. In the end, 8 studies were included in this systematic review, which were published between the years 2006 and 2015 .

All of the studies included in this review assessed the effect of vitamin A supplementation in the immediate postpartum period, they used supplementation with retinyl palmitate in 5 studies, 1 study with palmitate of retinyl and 2 studies did not specify the form of supplementation. Regarding the evaluated milk phase, 6 studies (75\%) assessed the colostrum and only 2 studies (25\%) included child supplementation.

Ribeiro et al. ${ }^{15}$ compared mothers supplemented with 200,000 IU of vitamin A with a control group, in order to check the effect on breast milk. The authors concluded that the use of megadose of vitamin A in the immediate postpartum increased retinol levels in the first 24 hours after supplementation, however, the increase was more effective in women with low levels of vitamin A in the colostrum. Bezerra et al. ${ }^{16}$ also investigated the effect of the supplementation of retinyl palmitate compared to a control group, however evaluated two periods, one in the postpartum period and thirty days after the supplementation dosage. In both periods evaluated, the retinol concentration in colostrum was higher in the group receiving the vitamin. In the long term, the authors found reduced retinol concentrations in colostrum after 30 days of the delivery. 


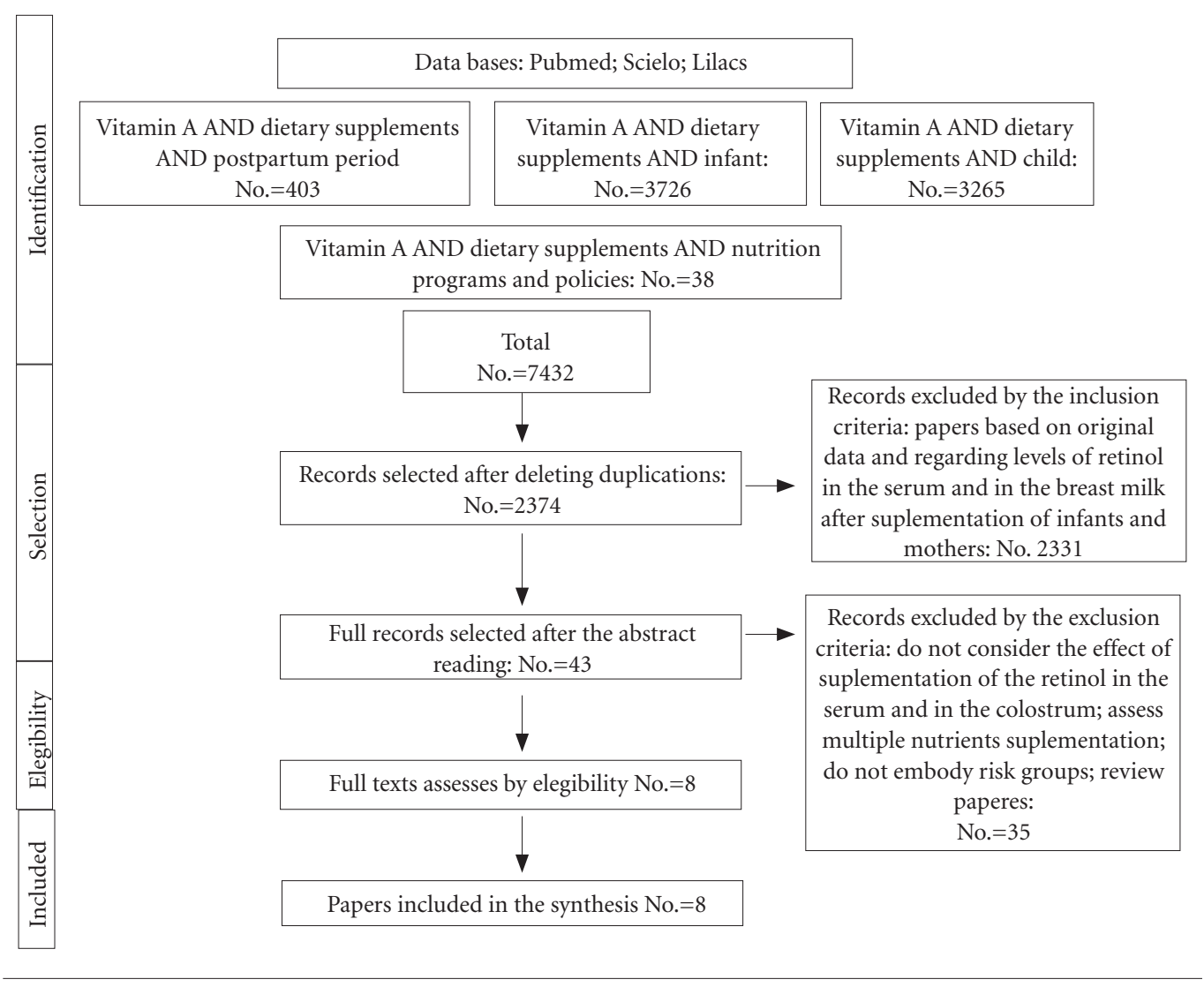

Figure 1. Identification and selection flowchart of papers for sistematic review of the Vitamin A supplementation.

Dimenstein et al. ${ }^{17}$ found that after supplementation with retinyl palmitate during the immediate postpartum period some mothers did not respond to it or had an increase in retinol concentration in the colostrum of less than $10 \%$. In addition, there was found an relation between serum retinol and the type of delivery, with a higher concentration of serum retinol in women who underwent vaginal delivery.

Tchum et al. ${ }^{18}$ evaluated the effect of vitamin A supplementation over time. The women were divided into 2 groups and both received 200,000 IU of vitamin A postpartum. After two weeks, the dosage of 200,000 IU was repeated for one group and to the other was given placebo. There was no difference in the results of serum retinol concentration for both groups.

The effect of vitamin A supplementation with retinyl palmitate was evaluated in three groups in the study by Bezerra et al. ${ }^{19}$, they are: one contemplated by women who received a single dose of 200,000 IU in the postpartum period, the second covering women who received double dose of 200,000 UI within a 24 hour interval between the supplementations and a third group which received no supplementation. Regarding the concentrations of vitamin A in the colostrum, no significant differences were found between the groups, however, retinol content in the mature milk differed from the unsupplemented group and the other groups. With regard to the double dose of Vitamin A compared to a single dose, it was not detected any statistically significant increases in the concentration of retinol in milk 4 weeks postpartum.

A study conducted by Grilo et al. ${ }^{20}$ used retinyl palmitate as a mean of supplementing, evaluating its effect on the retinol concentration in the colostrum before and after supplementation and in fasting and postprandial conditions. There was a higher concentration of retinol after supplementation (14.7\%) and after meal (43.8\%). 


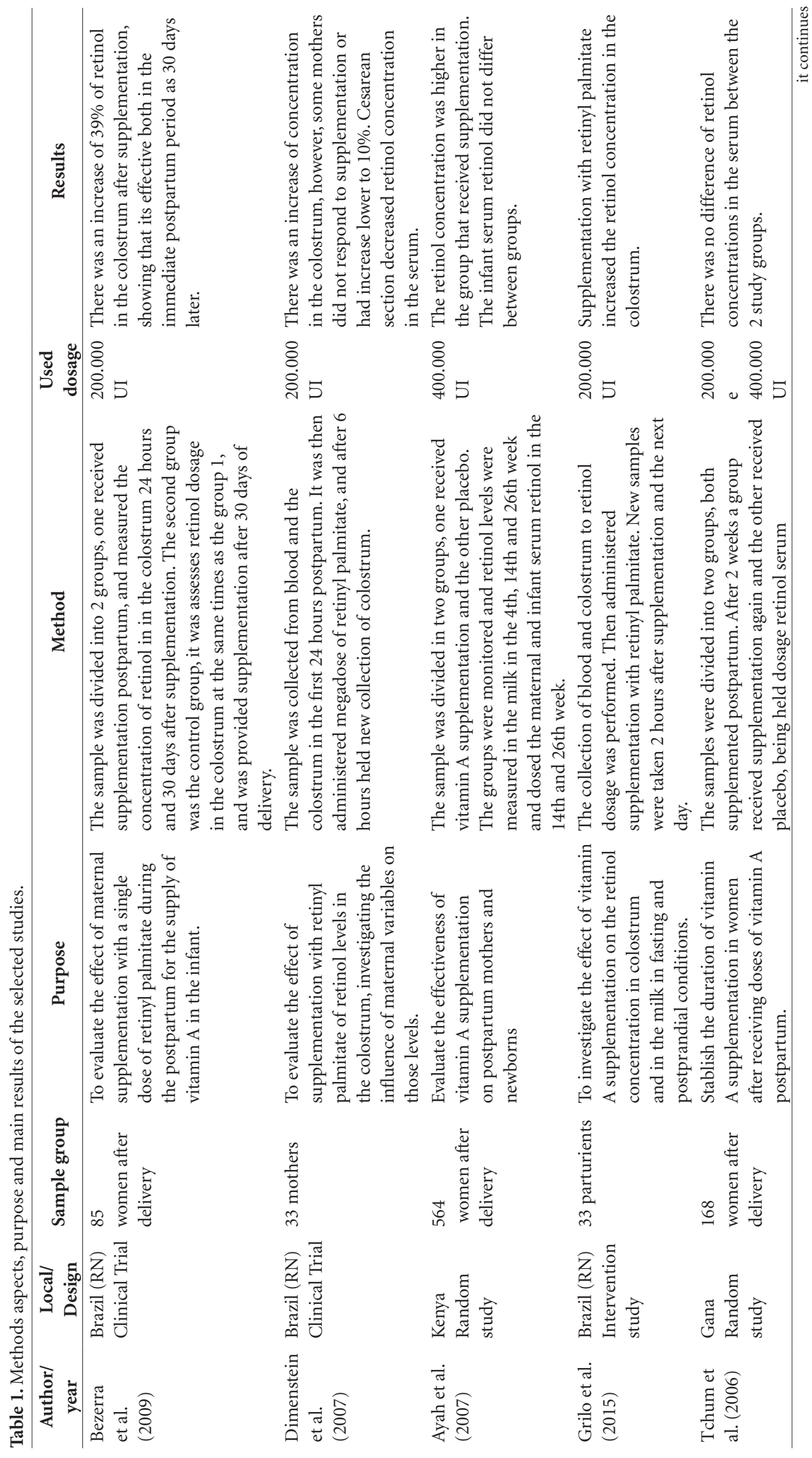




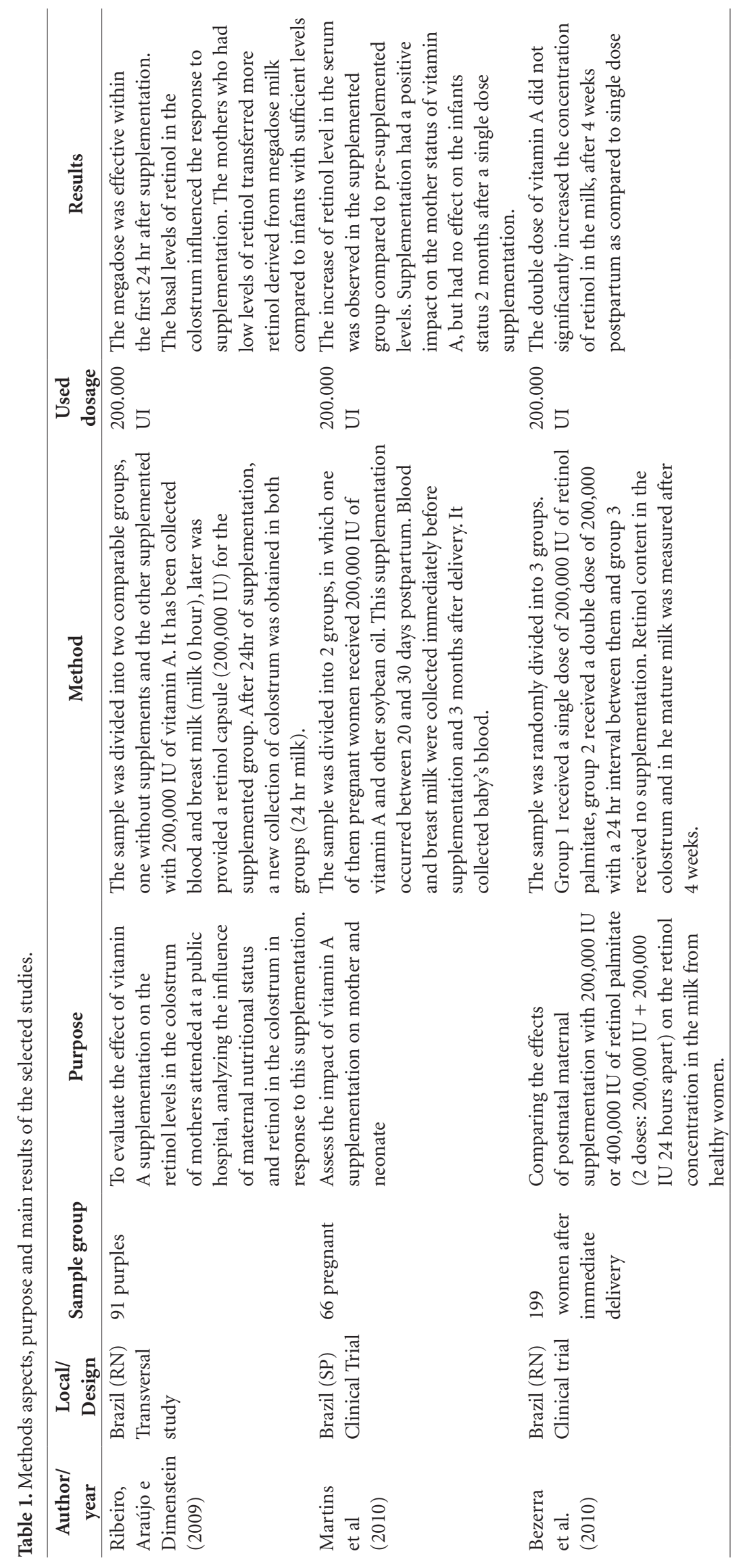




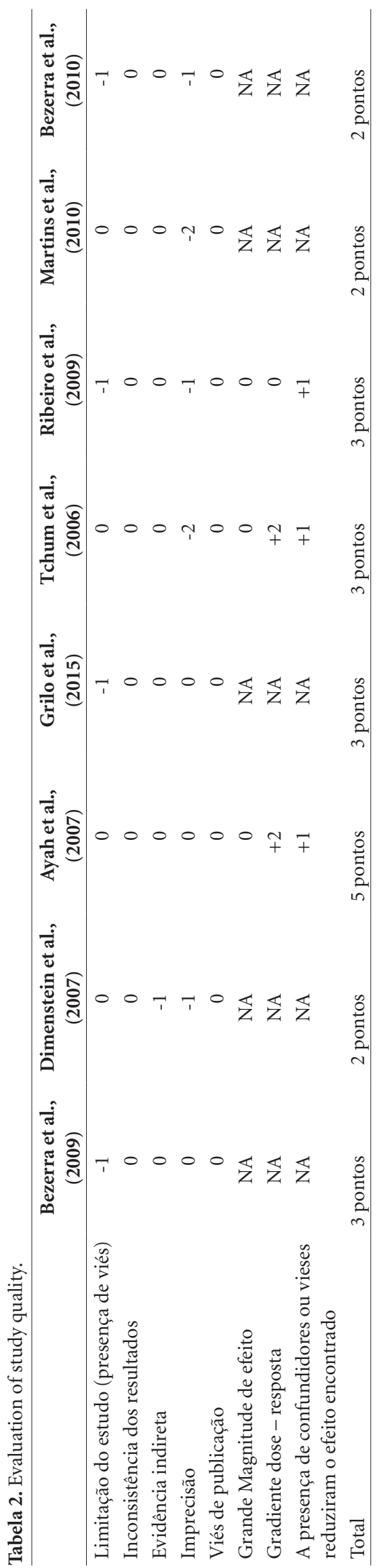

However, when evaluating the serum retinol levels before supplementation fasting and after supplementation and post-prandial situation, the increase was $219.4 \%$, showing the importance of associating supplementing and feeding.

Martins et al. ${ }^{21}$ compared supplemented pregnant women with 200,000 IU of vitamin A with a group that received soybean oil between the $20^{\text {th }}$ and $30^{\text {th }}$ day postpartum. There was a significant increase in serum retinol levels in the supplemented group compared to the pre-supplementation levels and the control group post-supplementation levels. The reduction of retinol in the breast milk was significantly higher in the control group compared to the pre-supplementation levels and the supplemented group after supplementation. There was a significant difference in the prevalence of VAD in the breast milk after supplementation, $55.6 \%$ in the control group and $16.1 \%$ in the supplemented group ( $\mathrm{P}$ $=0.002$ ). Deficiency of this vitamin was present in $66.1 \%$ of the infants, with average serum retinol levels of $0.64 \pm 0.30 \mathrm{mmol} / \mathrm{L}$ in the control group and $0.69 \pm 0.26 \mathrm{mmol} / \mathrm{L}$ in the supplemented group. This way, it is noticed that the supplementation had a positive impact on maternal status of vitamin A, but were found no effect on child state after two months of a single dose supplementation.

In a study conducted in Kenya, Ayah et al. ${ }^{22}$ evaluated the vitamin A supplementation in mothers and children, compared to a control group. In the postpartum, mothers received 400,000 IU, while the children received 100,000 IU. In the $4^{\text {th }}, 14^{\text {th }}$ and $26^{\text {th }}$ weeks after delivery was evaluated retinol dosage in the breast milk and in the $14^{\text {th }}$ and $26^{\text {th }}$ weeks the concentration of serum retinol in mothers and children. It was found as a result an increase in retinol concentration in the milk of the supplemented group and increased maternal serum retinol concentration, meanwhile the children serum retinol did not differ between the groups.

Finally, according to the studies analyzed, there is a positive influence between the vitamin A supplementation in postpartum and the increase of retinol concentration in the colostrum and in the maternal serum. However, studies were conflicting about the effects of supplementation at different periods of time.

In the quality evaluation of the studies, 3 were classified as low quality, 4 with medium quality and 1 with good quality. The risk possibility of selection bias is observed, since two studies had a convenience sample and another two did not 
mention how sample selection was performed. However, the studies that did not refer to the sample selection, performed statistical analysis to see if there were differences between the groups of the experiment and they did not differ. Regarding the sample size, only 2 studies did not refer to the accomplishment of this procedure. Thus, as it is not known if these studies are representative of the population, their results were not extrapolated to the Brazilian population. All the results presented by the articles were considered consistent, and the presence of publication bias was not verified.

\section{Discussion}

The findings of this study showed that supplementation with megadoses of vitamin A increases the serum retinol concentrations of the mother and in the breast milk, however, question the length of time that this increase remains. Moreover, some papers reflect on the relevance of maternal supplementation front the breast milk, which is considered the main food for the kids.

Bezerra et al. ${ }^{19}$ and Grilo et al. ${ }^{20}$ used retinyl palmitate as a form of supplementation, finding in their studies increase of retinol concentration in the colostrum and in the mature milk. In breast milk, vitamin $\mathrm{A}$ is present in the form of a retinyl ester, the main one being the retinyl palmitate ${ }^{23}$. Therefore, possibly supplementation with it would be the most effective way, because it refers to the way in which it is stored in the mammary glands.

Ribeiro et al. ${ }^{15}$ found that supplementation with 200,000 IU is able to increase the retinol levels in the colostrum after 24 hours of administration. It is believed that concentrations of vitamin $A$ are maintained high during the first few days of supplementation, as vitamin A stocks occurs in mammary epithelial tissue. Furthermore, part of the vitamin A derived of the supplements are directed preferably to the mammary gland, than to the liver, which permits supplementation of this nutrient in postpartum to be effective for the nutritional status of the infants ${ }^{24,25}$.

Bezerra et al. ${ }^{16}$ found similar results to Ribeiro et al. ${ }^{15}$, indicating higher retinol concentrations in the colostrum of women supplemented with 200,000 IU compared to the control group. Furthermore, long-term supplementation efficacy was observed, as was noted higher retinol concentration in the women colostrum after 30 days of supplement administration. However it should be considered that the recommendation of the Brazilian Ministry of Health is that supplementation of infants must occurs every 6 months ${ }^{12}$, thereby questioning the fact that 30 days is considered a long term effect in refering to the increase of retinol concentrations in the colostrum.

Both the studies, Bezerra et al. ${ }^{16}$ and Ribeiro et al. ${ }^{15}$ found reduced retinol concentrations in the colostrum 30 days after delivery, however, this reduction was lower in women who received supplementation when compared to the control group. In this sense, the importance of supplementation with regard to the ability to slow the reduction of retinol levels is emphasized, a important fact, assuming vitamin A plays a key role in the initial formation of the hepatic stores of vitamin A for infants.

Dimenstein et al. ${ }^{17}$ found in their study that not all nursing mothers responded to supplementation and some of them had less than the $10 \%$ increase in the concentration of retinol. In addition, this study found that women with low levels of vitamin A in the colostrum had a greater increase in retinol concentration in the colostrum. It is believed that there is a limit to the increase of vitamin A concentration in the breast milk, a fact related to the saturation of proteins involved in retinol transfer pathways from the blood to the mammary gland (lipoproteins and linker retinol protein ${ }^{26}$, as well as the enzymes involved in the transesterification and secretion of vitamin a in the colostrum. This mechanism is a adaptive type and are highly relevant to prevent excessive increase of retinol in the milk which could lead to toxicity of this micronutrient ${ }^{20}$.

A study by Ribeiro et al. ${ }^{15}$ found that women who had adequate intake of vitamin A in the milk probably had a greater role of the retinol proteins linker. Thus, after this vitamin supplementation, the transfer of retinol esters to the mammary gland becomes limited, unlike the lactating group who have low levels of retinol in the colostrum. In the latter case, the retinol protein linker has higher performance compared to the prior situation, until certain levels of saturation. This study agrees with Lima ${ }^{26}$ by showing that after vitamin A supplementation there is an increase in the transfer of retinyl esters to the mammary gland in lactating women who have low retinol levels in the colostrum.

Studies conducted in Ghana by Tchum et al. ${ }^{18}$ and Bezerra et al. ${ }^{19}$ demonstrated that supplementation in a short period of time, and with the upper recommended dosage (200,000 IU) were 
not effective in the improvement of retinol levels in the colostrum. Such situations may come from the fact that Vitamin A stock are already saturated, as shown in Lourenço ${ }^{27}$ study that the megadose in healthy women is able to maintain hepatic reserves and produce milk with a normal concentration of vitamin A for 60 days. These results represents the design of the vitamin A supplementation program created by the Brazilian Ministry of Health, which considers the use of only one vitamin A megadose (200,000 IU) orally in the immediate postpartum period ${ }^{12}$.

In the study by Bezerra et al. ${ }^{19}$ retinol concentrations in the colostrum of supplemented women were not statistically significant when compared to women not supplemented, however, this content differed when the milk stage analyzed was the mature milk. Colostrum is considered the first phase of breast milk secreted by the sixth day of the postpartum. It contains high concentrations of fat soluble vitamin, among them vitamin $\mathrm{A}^{28}$. Whereas the transition milk is secreted from the $7^{\text {th }}$ to $21^{\text {st }}$ day after the delivery and have large concentrations of this vitamin. The mature milk for it turns, keeps the concentration of vitamin A constant until the end of lactation, thus showing the actual nutrient intake for the children ${ }^{29,30}$. Forward these considerations, there is the importance of investigating vitamin A deficiency through the mature milk. In this sense, it is emphasized that more studies must be conducted to evaluate the concentration of this vitamin in the mature milk, since most of the papers included in this review evaluated only the colostrum.

Therefore, in the study of Grilo et al. ${ }^{20}$ were measured retinol levels in the colostrum before and after supplementation, and period of fasting and postprandial, verifying that retinol concentrations were higher after supplementation and meals. In this sense, it is clear that food is also able to increase concentrations of this vitamin in the breast milk, making us reflect on the relevance of supplementation in all women without first knowing the nutritional status of vitamin A, as in the study Bezerra et al. ${ }^{19}$ found no statistical differences in retinol concentrations in the colostrum after supplementation in women. This may be related to adequate nutritional status of vitamin A for postpartum women. Studies show that nutritional status is the factor that has the most influence on vitamin A concentrations in the body ${ }^{11,31}$.

Martins et al. ${ }^{21}$ found no effect of vitamin A supplementation with a single dose over the infant status two months after supplementation.
According to Silva ${ }^{23}$, retinol found in the breast milk has good availability and is easily absorbed by the infant's body. However, despite the breast milk of nursing mothers with inadequate nutritional status be able to meet the metabolic needs of the infant, their concentrations are not sufficient to promote the generation of vitamin stock $^{23}$. It is believed then that maternal supplementation increased the retinol concentration in the colostrum, but not enough to generate changes in serum levels of the child, is not effective in infants due to maternal nutritional status. To Black et al..$^{32}$, the risk of a newborn have their reserves depleted is greater when there is maternal micronutrient deficiencies. Thus, the vitamin A content in the breast milk is the main determinant of the nutritional status of that vitamin in the newborn.

With regard to the supplementation of children, Ayah et al. ${ }^{22}$ found that after $14^{\text {th }}$ and $26^{\text {th }}$ weeks of vitamin A supplementation (100,000 IU) no differences were found between those supplemented and unsupplemented. It must be considered that the supplementation offered to these children are in accordance with the recommendation of the Brazilian Ministry of Health, which proposes higher dose (200,000 IU) only after 12 months of age and up to 59 months, 6 months spacing ${ }^{12}$. According to Lima et al..$^{28}$, vitamin A supplementation in the period of childhood is given as a public health strategy to improve child survival and reduce the risk of morbidity from infectious disease ${ }^{28}$, as this age group is among the most vulnerable to the develop vitamin A deficiency ${ }^{33,34}$. However, the effectiveness of this supplementation in this age group must be studied, as in this review only two studies addressed supplementation in children.

According to a literature review conducted by Mason et al. ${ }^{13}$, vitamin A supplementation policies should be rethought, since studies have found no effect of supplementation on serum retinol in children after 2 months of megadose administration. Thus, the authors emphasize the importance of working issues that reinforce the importance of daily intake of this vitamin, also highlighting the fortification of foods and regular supplementation with low doses ${ }^{13}$.

The lack of publications related to the assessment of vitamin A for long-term supplementation, stands out as a limitation of this study, as well as studies evaluating supplementation in children. However, it emphasizes the relevance of this study to investigate the effect of vitamin A supplementation, given the high prevalence of 
vitamin A deficiency even after the implementation of this vitamin supplementation programs.

\section{Conclusion}

From this systematic review, it can be concluded that supplementation with megadoses of vitamin $A$ in the postpartum period can increase serum retinol concentrations in the breast milk. However, this effect was evidenced in a short term situation, being more relevant when the previous levels are low.

In regard to maternal supplements and their effect on children, it is believed that the megadose is relevant when the parent retinol levels are insufficient, since in these cases there is a greater transfer of this vitamin for the mammary gland. In contrast, when the mother's retinol levels are adequate, there are few changes in the concentra- tions of this vitamin in the breast milk, therefore there is less relevant for the children.

Another important finding of this review refers to the children's supplementation, it highlights the importance that more studies should be conducted to evaluate the effect of supplementation with megadoses in serum concentrations of this age group, as there were identified only two studies that nanalyzed this regarding $i$ this review.

The studies are still inconclusive as to the real benefit of megadoses supplementation in children and nursing mothers, regarding serum retinol and human milk. In view of this, we emphasize the importance of further studies aimed at evaluating the vitamin A effectiveness megadoses supplementation program, since this deficiency causes a number of public health problems and this is a program that many countries have not adhered to.

\section{Collaborations}

MM Soares, MA Silva and PPC Garcia participated in the article design, information gathering, analysis and writing. LS Silva, GD Costa, RMA Araújo and RMM Cotta contributed to the revision and adequacy of the text. 


\section{References}

1. Underwood BA. Maternal vitamin A status and its importance in infancy and early childhood. Am J Clin Nutr 1994 [acessado 2016 Mar 21]; 59(2 Supl.):517524S. Disponível em: http://www.ajcn.org/content /59/2/517S.full.pdf.

2. United Nations International Children's Emergency Fund (Unicef), The Micronutrient Initiative (MI), World Health Organization (WHO), The Canadian International Development Agency (CIDA), US Agency for International Development (USAID). Vitamin Global Initiative. A strategy for acceleration of progress in combating Vitamin A. New York: Unicef; 1997. 18-19p. [acesso em 2016 jun. 14]. Disponível em: http://www. unicef.org/immunization/files/Vit_A_strategy.pdf

3. Mclaren DS, Frigg M. Sight and life manual on vitamin A deficiency disorders. $2^{\text {nd }}$ ed. Switzerland: Task Force 2001. [acessado 2016 Mar 18]. Disponível em: http:// www.sightandlife.org/fileadmin/data/Books/Manual_on_Vitamin_A_(vadd)_e.pdf

4. World Health Organization (WHO). Global prevalence of vitamin A deficiency in populations at risk 1995-2005: WHO global database on vitamin A deficiency. Geneva: WHO; 2009.

5. Brito VRS. Intervenção educativa envolvendo trabalhadores de saúde do Programa Nacional de Suplementação de Vitamina A [dissertação]. Recife: Universidade Federal de Pernambuco; 2011.

6. Mclaren DS, Kraemer K. Manual on Vitamin A Deficiency Disorders. (VADD). $3^{\text {th }}$ ed. Geneva: Task Force; 2012. [acessado 2016 Mar 21]. Disponível em: http:// www.sightandlife.org/fileadmin/data/Books/vitamin_a_deficiency_disorders_VADD.pdf.

7. Brito VRS. Percepção de profissionais da saúde sobre o Programa brasileiro de combate a Deficiência de Vitamina $A$ [tese]. Recife: Universidade Federal de Pernambuco; 2015.

8. Brasil. Ministério da Saúde (MS). Pesquisa Nacional de Demografia e Saúde da criança e da mulher PNDS 2006: dimensões do processo reprodutivo e da saúde da criança. Série G. Estatística e Informação em Saúde. Brasília: MS 2009. [acessado 2016 Maio 20]. Disponível em: http:// bvsms.saude.gov.br/bvs/publicacoes/pnds_crianca_ mulher.pdf.

9. Silva LLS, Peixoto MRG, Hadler MCCM, Silva SA, Cobayashi F, Cardoso MA. Estado nutricional de vitamina A e fatores associados em lactentes atendidos em Unidades Básicas de Saúde de Goiânia, Goiás, Brasil. Rev Bras Epidemiol 2015; 18(2):490-502.

10. Brasil. Portaria 729, de 13 de maio de 2005. Institui o Programa Nacional de Suplementação de Vitamina A e dá outras providências. Diário Oficial da União 2005; 16 maio.

11. Ramalho A. Funções plenamente reconhecidas de nutrientes: Vitamina A. ILSI Brasil 2010; 12:1-28.

12. Brasil. Ministério da Saúde (MS). Manual de Condutas Gerais do Programa Nacional de Suplementação de Vitamina A. Brasília: MS; 2013.

13. Mason J, Greiner T, Shrimpton R, Sanders D, Yukich J. Vitamin A policies need rethinking. Int J Epidemiol 2015; 44(1):283-292.

14. Moher D, Liberati A, Tetzlaff J, Altman DG. PRISMA Group. Preferred reporting items for systematic reviews and meta-analyses: the PRISMA statement. Ann Intern Med 2009; 151(4):264-269.
15. Ribeiro KDS, Araújo KF, Dimenstein R. Efeito da suplementação com vitamina A sobre a concentração de retinol no colostro de mulheres atendidas em uma maternidade pública. Rev Assoc Med Bras 2009; 55(4):452457.

16. Bezerra DS, Araújo KF, Azevêdo GMM, Dimenstein R. Suplementação materna com retinil palmitato no pós -parto imediato: consumo potencial por lactentes. Rev Saúde Pública 2009; 43(4):572-579.

17. Dimenstein R, Lourenço RMS, Ribeiro KDS. Impacto da suplementação com retinil palmitato no pós-parto imediato sobre os níveis de retinol do colostro. Rev Panam Salud Pública 2007; 22(1):51-54.

18. Tchum SK, Tanumihardjo SA, Newton S, Benoist B, Owusu-Agyei S, Arthur FKN, Tetteh A. Evaluation of vitamin A supplementation regimens in Ghanain postpartum mothers with the use of the modified-relative-dose-response test. Am J Clin Nutr 2006; 84(6):1344-1349.

19. Bezerra DS, Araújo KF, Azevêdo GMM, Dimenstein R. A randomized trial evaluationg the effect of 2 regimens of maternal vitamin A supplementation on breast milk retinol levels. J Hum lact, 2010; 26(2):148-156.

20. Grilo EC, Lima MSR, Cunha LRF, Gurgel CSS, Clemente HA, Dimenstein R. Effect of maternal vitamin A supplementation on retinol concentration in colostrum. J Pediatr 2015; 91(1):81-86.

21. Martins TM, Ferraz IS, Daneluzzi JC, Martinelli Júnior CE, Del Ciampo LA, Ricco RG, Jordão AA Jr, Patta MC, Vannucchi H. Impact of maternal vitamin A supplementation on the mother-infant pair Brazil. Eur JClin Nutr 2010; 64(11):1302-1307.

22. Ayah RA, Mwaniki DL, Magnussen P, Tedstone AE, Marshall T, Alusala D, Luoba A, Kaestel P, Michaelsen KF, Friis $\mathrm{H}$. The effects of maternal and infant vitamin A supplementation on vitamin A status: a randomized trial in Kenya. J Nut 2007; 98(2):422-430.

23. Silva KVN. Retinol, carotenoides e tocoferóis do leite humano e aspectos antropométricos, bioquímicos e dietéticos de nutrizes adolescentes e adultas [dissertação]. Viçosa: Universidade Federal de Viçosa; 2014.

24. Green MH, Green JB, Akohoue SA, Kelley SK. Vitamin A intake affects the contribution of chylomicrons vs. retinol-binding protein to milk vitamin A in lactating rats. J Nutr 2001; 131(4):1279-1282.

25. Ross AC, Pasatiempo AM, Green MH. Chylomicron margination, lipolysis, and vitamin a uptake in the lactating rat mammary gland: implications for milk retinoid content. Exp Biol Med (Maywood). 2004; 229(1):46-55

26. Lima MSR. Avaliação da concentração de vitamina A materna e de neonatos prematuros e a termo [dissertação]. Natal: Universidade Federal do Rio Grande do Norte; 2015

27. Lourenço RMS. Influência da suplementação de retinol palmitato sobre os níveis de vitamina A do leite de puérperas saudáveis [dissertação]. Natal: Universidade Federal do Rio Grande do Norte; 2005.

28. Lima MSR, Ribeiro PPC, Medeiros JMS, Silva IF, Medeiros ACP, Dimenstein R. Influênce of postpartum supplementation with vitamin A on the levels of immunoglobulin A in human colostrum. J Pediatr 2012; 88(2):115-118. 
29. Oliveira JM, Oliveira NS, Bergamaschi DP. Concentrações de vitamina A no leite humano e características socioeconômicas e nutricionais maternas: resultados de estudos brasileiros. Rev Bras Saúde Matern Infant 2009; 9(1):11-20.

30. Souza G, Saunders C, Dolinsky M, Queiroz J, Campos A, Ramalho A. Vitamin A concentration in mature human milk. J Pediatr 2012; 88(6):496-502.

31. Tomiya MTO. Efeito da suplementação de 400.000UI versus 200.000UI de palmitato de retinol no post partum imediato nas concentrações de retinol do leite materno [dissertação]. Recife: Universidade Federal de Pernambuco; 2014.

32. Black RE, Allen LH, Bhutta ZA, Caulfield LE, Onis M, Ezzati M, Mathers C, Rivera J; Maternal and Child Undernutrition Study Group. Maternal and child undernutrition: global and regional exposures and health consequences. Lancet 2008; 371(9608):243-260.

33. Fernandes TFS, Diniz AS, Cabral PC, Oliveira RS, Lóla MMF, Silva SMM, Kolsteren P. Hipovitaminose A em pré-escolares de creches públicas do Recife: indicadores bioquímico e dietético. Rev Nut 2005. 18(4):471-480.

34. Pedraza DF. Evidências do impacto da suplementação múltipla com micronutrientes no crescimento de pré -escolares: revisão sistemática. Rev Bras Saúde Matern Infant 2014; 14(1):17-37.

Artigo apresentado em 08/12/2016

Aprovado em 10/05/2017

Versão final apresentada em 12/05/2017 